\title{
Overheidssteun voor religie: antiperfectionisme of perfectionisme?
}

\author{
Leni Franken
}

\section{$1 \quad$ Inleiding}

Sinds de publicatie van Rawls' A Theory of Justice ${ }^{1}$ is de neutraliteit van de overheid een centraal begrip geworden in de liberale politiek-filosofische theorie: opdat alle burgers een leven kunnen leiden 'volgens de waarden die ze onderschrijven' ${ }^{2}$ dient de overheid 'neutraal' of 'antiperfectionitstich' te zijn in haar beleidsformulering: politieke beslissingen mogen niet de bedoeling hebben om particuliere opvattingen van het goede leven te bevoordelen of mensen voor te trekken omdat ze zich tot een bepaalde opvatting van het goede leven bekennen. ${ }^{3}$ In hun formulering mogen deze beslissingen dan ook geen voorkeur vertonen voor een welbepaalde levensbeschouwing:

'[T] he state is not to do anything intended to favor or promote any particular comprehensive doctrine rather than another, or to give greater assistance to those who pursue it.'

Voor dit antiperfectionistische of neutrale beleid is een autonomy-based justification de meest gebruikte en geaccepteerde legitimering: uit respect voor de menselijke vrijheid en het recht tot onafhankelijke zelfbepaling moet een liberale overheid zich terughoudend opstellen als het gaat over de waardering van de verschillende levensbeschouwingen en opvattingen van het goede leven die burgers erop

1 John Rawls, A Theory of Justice (Harvard: Harvard University Press, 1971).

2 Will Kymlicka, Liberalism, Community and Culture (Oxford: Oxford University Press, 1989), 12; idem, Contemporary Political Philosophy. An Introduction (New York: Oxford University Press, 2002), 216.

3 Hoewel Rawls meent dat de neutraliteitseis enkel noodzakelijk is voor de "basic structure of society' (Rawls, A Theory of Justice, 8) en op “'constitutional essentials” and questions of basic justice' (John Rawls, Political Liberalism [New York: Columbia University Press, 2005 (1993)], 181, 308-9) en hij meent dat deze neutraliteitseis enkel 'highly desirable' (Rawls, Political Liberalism, 215) is wanneer het gaat over andere politieke aangelegenheden, ben ik net zoals Jonathan Quong (Liberalism without Perfection [Oxford: Oxford University Press, 2011], 275) van mening dat het principe van neutraliteit dient te worden nagestreefd bij alle politieke beslissingen waarbij de staat macht uitoefent over haar burgers. Enkel op die manier is de overheid niet dwingend of paternalistisch.

4 John Rawls, 'The Priority of Right and Ideas of the Good,' Philosophy and Public Affairs 17(4) (1988): 262. 
nahouden. ${ }^{5}$ Liberalen pleiten met andere woorden 'voor vrijheid door te argumenteren tegen perfectionisme'. ${ }^{6}$

Maar wat houdt deze neutraliteitseis precies in? Betekent het dat de overheid enkel zaken mag ondersteunen die in het algemene belang zijn? Of mag de overheid ook zaken ondersteunen omdat ze voor een aantal burgers waardevol zijn? En wat betekent dit neutrale beleid voor de financiële ondersteuning van religies en nietconfessionele levensbeschouwingen ${ }^{7}$ ? Moet een overheid, om daadwerkelijk neutraal te zijn, van dergelijke steun afzien en een hands-offbeleid inzake religie voeren, of is het toch toegelaten om binnen een neutraal of antiperfectionistisch beleid één of meerdere levensbeschouwingen te ondersteunen?

In wat volgt ga ik dieper in op deze vragen. $\mathrm{Na}$ een conceptuele verheldering toon $\mathrm{ik}$ aan dat religie een perfectionistisch goed is. Daarna argumenteer ik dat er vanuit het autonomy-based liberalisme een neutrale of antiperfectionistische legitimering mogelijk is om perfectionistische goederen - en dus ook religies - te ondersteunen. Dergelijke steun kan er immers toe bijdragen dat er meerdere 'waardevolle opties' zijn waaruit burgers kunnen kiezen, en dat is een van de noodzakelijke mogelijkheidsvoorwaarden voor autonomie.

Vervolgens ga ik na wat een perfectionistisch goed tot een waardevolle optie maakt en wanneer een steunbeleid legitiem is. Mij baserend op het werk van Ben Colburn toon ik aan dat steun voor 'waardevolle opties' enkel legitiem is om gelijke toegang tot autonomie te verschaffen en dat niet de intrinsieke waarde van, maar wel democratische consensus over een bepaalde optie deze optie waardevol maakt. Dit impliceert dat de keuze om perfectionistische goederen te ondersteunen steeds gebaseerd zal moeten zijn op democratische onderhandelingen: wanneer burgers geen vragende partij zijn voor een (specifiek) steunbeleid of wanneer gelijke toegang tot autonomie gerealiseerd kan worden zonder steunbeleid, is er in principe geen reden voor de overheid om perfectionistische goederen financieel te ondersteunen.

Hieruit volgt dat zowel de grondwettelijke verplichting om religie (een perfectionistisch goed) te ondersteunen, alsook het grondwettelijke verbod om religie te ondersteunen, verkeerd zijn: hoewel de overheid wel een neutraal argument kan geven voor haar ondersteuningsbeleid van perfectionistische goederen, moet haar keuze om religie (en gelijk welk ander perfectionistisch goed) in het bijzonder te ondersteunen, steeds gebaseerd zijn op deliberatieve consensus en mag deze dus niet (grond)wettelijk worden verankerd. Omwille van gelijkaardige redenen is ook het grondwettelijk verbod om religies te ondersteunen problematisch. Dergelijke steun mag immers wel gegeven worden als burgers hierom vragen en wanneer dit leidt tot gelijke toegang tot autonomie, en mag dus niet a priori worden uitgesloten.

5 Andrew Mason, 'Autonomy, Liberalism and State Neutrality,' The Philosophical Quarterly 40(161) (1990): 433-34.

6 Tim Wolff, Multiculturalisme en Neutraliteit (Amsterdam: Vossiuspers UvA, 2005), 13.

7 Voorbeelden hiervan zijn het boeddhisme en het vrijzinnig humanisme. 
Ten slotte toon ik aan dat overheidssteun voor religie (en voor andere perfectionistische goederen) enkel legitiem is wanneer er aan een aantal objectieve criteria is voldaan.

\section{Liberalisme en autonomie}

Volgens het liberalisme van John Rawls (en met hem ook vele andere liberale filosofen) moet ieder individu op zijn minst de mogelijkheid hebben om zijn of haar opvattingen over het goede leven 'te vormen, te herzien en te realiseren'. ${ }^{8}$ Hoewel de latere Rawls afstand neemt van het idee dat burgers best het principe van autonomie ook in hun private leven onderschrijven, is zijn politiek liberalisme uiteindelijk nog steeds gebaseerd op een 'dunne' opvatting van het goede leven: binnen een liberale samenleving moeten burgers immers minstens de mogelijkheid hebben om autonome keuzes te kunnen maken. Of ze van deze mogelijkheid gebruik maken of niet, doet in principe niet ter zake (en hiermee distantieert Rawls zich van zijn vroegere werk), maar de mogelijkheid moet wel gegarandeerd zijn. Rawls neemt dus ook in zijn latere werk een specifiek normatief standpunt in, waarin autonomie een centrale rol speelt. Hierdoor is ook zijn politiek liberalisme comprehensive en niet enkel political zoals hij zelf beweert. ${ }^{9}$

Dit 'dunne' autonomy-based liberalisme blijkt een erg consistente liberale theorie die een adequaat framework biedt voor de liberale neutraliteitseis: uit respect voor de menselijke vrijheid en het recht tot onafhankelijke zelfbepaling vloeit immers de eis tot overheidsneutraliteit of antiperfectionisme voort. Om autonome keuzes mogelijk te maken, moet een liberale overheid zich terughoudend opstellen als het gaat over de waardering van de verschillende levensbeschouwingen en opvattingen van het goede leven die burgers erop nahouden. De overheid moet dus neutraal of antiperfectionistisch zijn, wat betekent dat ze haar beleid niet mag baseren op een welbepaalde opvatting over het goede leven (een comprehensive doctrine).

In wat volgt vertrek ik van dit dunne autonomy-based liberalisme en ga ik na of en hoe een actief ondersteuningsbeleid voor (religieuze en niet-religieuze) levensbeschouwingen binnen een dergelijk liberaal denkkader gelegitimeerd kan worden, zonder dit liberale denkkader zelf te ondermijnen. Daarnaast ga ik na hoe een dergelijk beleid in overeenstemming kan zijn met de - op autonomie gebaseerde - eis tot overheidsneutraliteit of antiperfectionisme.

8 Rawls, Political Liberalism, 19.

9 Zie hierover bijv. Will Kymlicka, 'Two Models of Pluralism and Tolerance', Analyse \& Kritik 13 (1992): 45-46; Andrew Mason, Autonomy, Liberalism and State Neutrality, 445ff; Ben Colburn, Autonomy and Liberalism (New York: Routledge, 2010), 65. 


\section{Publiek of niet-publiek? Perfectionistisch of niet-perfectionistisch?}

Om burgers niet enkel formeel, maar ook reëel de kans te geven een leven te leiden volgens de principes die zij onderschrijven, moet de liberale overheid volgens Rawls (en met hem vele andere denkers) een aantal primary goods - goederen die iedereen ten goede (kunnen) komen en dus voor iedereen toegankelijk moeten zijn - garanderen. Hiertoe hebben we nood aan een aantal zaken zoals onderwijs, gezondheidszorg en nationale defensie. ${ }^{10}$ Deze zaken zijn steeds 'in het algemene belang, ${ }^{11}$ en zijn een mogelijkheidsvoorwaarde voor eenieders welzijn, wat dat ook moge zijn. Omwille van conceptuele duidelijkheid zal ik deze zaken nietperfectionistische goederen noemen: het algemene belang ervan kan immers op een neutrale manier (vanuit de original position) worden aangetoond.

Daarnaast zijn er ook heel wat zaken die niet noodzakelijk zijn om iedereen gelijke kansen te geven, maar die sommige burgers wel waardevol kunnen vinden. Voorbeelden zijn kunst, sport, reizen en uitgaan; of concreter: schilderkunst en theater; tennis en ijshockey; een trip naar Londen en een reis naar Ibiza; een avond uit eten of een nacht in een nachtclub. Deze zaken zal ik in mijn betoog perfectionistische goederen noemen: het belang ervan kan immers niet op een neutrale manier worden beargumenteerd.

Zowel perfectionistische als niet-perfectionistische goederen kunnen door de overheid met collectieve (publieke) middelen ondersteund worden. In dit geval kunnen we spreken we over publieke goederen. ${ }^{12}$ Voor niet-perfectionistische goederen (bijv. onderwijs, nationale defensie en gezondheidszorg) kan dit soort overheidssteun eenvoudig gelegitimeerd worden: omdat deze goederen in het algemene belang zijn en bijdragen tot eenieders welzijn, kan het legitiem zijn om deze als overheid te ondersteunen met collectief belastinggeld. Dit wil echter niet zeggen dat niet-perfectionistische goederen altijd door de overheid gesubsidieerd moeten worden. Sommige niet-perfectionistische goederen worden immers niet door de overheid gesubsidieerd omdat ze ook zonder overheidssteun kunnen bestaan, of omdat ze niet door de overheid gesubsidieerd kunnen worden. Voorbeelden hier zijn zuivere lucht en propere oceanen, maar ook vriendschap, liefde, vertrouwen en respect. Iedereen heeft belang bij deze zaken, maar ze kunnen niet via

10 Rawls gebruikt hier de term public goods, maar deze terminologie schept verwarring. Zie hierover noot 12 .

11 Rawls, A Theory of Justice, 97, 267.

12 De term 'public goods' wordt bij Rawls (en elders in de vakliteratuur) vaak in verschillende betekenissen gebruikt, wat voor verwarring zorgt. Zo vallen bij Rawls niet alleen goederen die in het algemene belang zijn (niet-perfectionistische goederen) onder de noemer public goods, maar ook zaken die niet in het algemene belang zijn, maar wel met collectieve middelen gesubsidieerd worden (bijv. kunst), noemt hij public goods. Omwille van conceptuele duidelijkheid kies ik voor een andere terminologie: zaken die niet noodzakelijk in het algemene belang zijn duid ik aan met de term 'perfectionistisch' - verwijzend naar hun perfectionistische of niet-neutrale legitimering -, terwijl ik de term 'niet-perfectionistisch' verkies voor goederen die in het algemene belang zijn en waarvoor overheidssteun bijgevolg op een neutrale of antiperfectionistische manier (bijv. vanuit de original position) gelegitimeerd kan worden. Zowel perfectionistische als niet-perfectionistische goederen kunnen publiek (gesubsidieerd met overheidsmiddelen) als niet-publiek zijn. 
incentives van de overheid gerealiseerd worden. Kortom, niet-perfectionistische goederen kunnen zowel publiek (met collectief belastinggeld gesubsidieerd) als niet-publiek (niet met publiek belastinggeld gesubsidieerd) zijn.

Anders dan bij niet-perfectionistische goederen, kan het nut of de waarde van perfectionistische goederen niet op een neutrale manier worden aangetoond. Daarom lijkt er niet meteen een legitieme reden te zijn om deze goederen ook als overheid te subsidiëren. Deze conclusie is echter te voorbarig. Er blijken immers in de praktijk heel wat perfectionistische goederen te zijn die de overheid met collectieve middelen ondersteunt: denk maar aan subsidies voor musea, theater- en operavoorstellingen, muziekscholen, sportclubs, zwembaden, dierenparken, jeugdbewegingen enzovoort. Perfectionistische goederen kunnen dus (net zoals nietperfectionistische goederen) zowel publiek als niet-publiek zijn. De vraag is echter of en hoe een actief ondersteuningsbeleid van perfectionistische goederen te rijmen valt met een neutraal of antiperfectionistisch overheidsbeleid en met het idee dat alle burgers minstens de mogelijkheid moeten hebben om autonome keuzes te kunnen maken en hun leven in te richten op basis van deze keuzes. Vooraleer ik op deze vraag inga, ga ik na of levensbeschouwingen, en in het bijzonder georganiseerde of geïnstitutionaliseerde levensbeschouwingen, perfectionistische of nietperfectionistische goederen zijn. Het antwoord hierop zal immers bepalend zijn voor de manier waarop de overheid levensbeschouwingen al dan niet actief mag ondersteunen.

\section{Zijn levensbeschouwingen niet-perfectionistische goederen?}

In de negentiende eeuw noemde de Duitse filosoof Arthur Schopenhauer de mens een animal metaphysicum en wees hij erop dat zowel religie als filosofie een antwoord willen geven op 'de metafysische behoefte van de mens' ${ }^{13}$ In dezelfde lijn wijst Martha Nussbaum op de menselijke interesse in metafysische vragen en stelt ze dat religie 'van groot belang en kostbaar' is. ${ }^{14}$

Onze gedeelde interesse in metafysische vraagstukken en onze zoektocht naar de zin van het leven zijn zonder twijfel onmiskenbare feiten. Maar impliceert deze zoektocht naar zin en betekenis ook dat religies (en niet-religieuze levensbeschou-

13 Arthur Schopenhauer, De wereld als wil en voorstellingII (Amsterdam: Wereldbibliotheek, 1997), 202-238.

14 Martha Nussbaum, Liberty of Conscience: In Defence of Americas Tradition of Religious Equality (New York: Basic Books, 2008), 9. 
wingen $)^{15}$ in eenieders belang zijn? Volgens Tariq Modood blijkt dit alvast het geval te zijn. Volgens hem is religie

'(...) a fundamental good and part of our humanity at a personal, social and civilizational level: it is an ethical good and so to be respected as a feature of human character just as we might respect truth-seeking, the cultivation of the intellect or the imagination or artistic creativity or self-discipline not just because of its utility or truth.'

Of we nu zelf geloven of niet, religie is een intrinsiek goed en de mensheid zou slechter af zijn zonder, aldus Modood. ${ }^{16}$ Daarom moeten we religie niet opvatten als een 'private benefit', maar als een 'public good or national resource' dat de overheid in sommige gevallen kan ondersteunen.

Omwille van een ietwat andere reden stellen ook auteurs zoals Robert Bellah, Jean-Jaques Rousseau en Alexis De Tocqueville dat religie in het algemene belang is: religie beïnvloedt het menselijke gedrag en de ethiek op een positieve manier, draagt bij aan de sociale cohesie en komt daarom heel de samenleving ten goede. $^{17}$

Als levensbeschouwingen inderdaad in het algemene belang zijn en dus nietperfectionistische goederen zijn, kan overheidssteun voor levensbeschouwelijke organisaties eenvoudig gelegitimeerd worden: omdat levensbeschouwing, net zoals bijvoorbeeld onderwijs en gezondheidszorg, heel de samenleving ten goede komt, mogen particuliere levensbeschouwelijke organisaties (net zoals scholen en ziekenhuizen) door de overheid ondersteund worden. Dit kan betekenen dat de overheid salarissen en pensioenen van clerici en moreel afgevaardigden betaalt; dat ze gebouwen die voor levensbeschouwelijke doeleinden worden gebruikt subsidieert; dat ze liturgische voorwerpen en plaatsen financiert; dat ze religieuze non-profitorganisaties en verenigingen ondersteunt; enzovoort.

15 Ik vat religie/levensbeschouwing hier op in de brede zin van het woord, met name als een samenhangend geheel van overtuigingen en praktijken waarmee mensen zich verhouden ten aanzien van wat hen overstijgt (het transcendente), zonder hierbij noodzakelijk in één of meerdere transcendente entiteit(en) te geloven. Volgens religiewetenschapper Ninian Smart zijn er in de meeste religies/levensbeschouwingen zeven dimensies te onderkennen: rituelen, mythen, doctrines, emoties, morele waarden, sociale structuur en kunst (Ninian Smart, Secular Education and the Logic of Religion [New York: Humanities Press, 1968], 104). Omdat niet alle kenmerken (even sterk) naar voor komen in elke levensbeschouwing afzonderlijk, kunnen we de verschillende dimensies beter beschouwen als familiegelijkenissen - kenmerken die vaak, maar niet noodzakelijk voorkomen bij alle levensbeschouwingen, maar die allemaal samen toch het concept kunnen verhelderen.

16 Tariq Modood, 'Moderate Secularism, Religion as Identity and Respect for Religion', The Political Quarterly 81(1) (2010): 12.

17 Voor een recent overzicht van een aantal argumenten die worden aangehaald om religie als 'bijzonder' op te vatten, zie bijv. Gemma Cornelissen, 'Belief-Based Exemptions: Are Religious Beliefs Special?', Ratio Juris 25(1) (2012): 85-109. 
Vandaag de dag is het echter helemaal niet (meer) zo vanzelfsprekend om levensbeschouwingen op te vatten als niet-perfectionistische goederen. Recente ontwikkelingen zoals secularisering, (mentale) ontzuiling, detraditionalisering en individualisme, maar ook religieus fundamentalisme, religieus geïnspireerd terrorisme en religieuze intolerantie, maken dat een consensus over de waarde en het belang van levensbeschouwingen anno 2015 ver te zoeken is. In het verlengde hiervan blijkt (een gedeelde) religie ook niet (langer) noodzakelijk voor de moraal en sociale cohesie in de samenleving. Meer zelfs: vaak zorgt religieuze diversiteit in de samenleving voor conflict en wrijvingen, en niet voor cohesie en een gedeelde moraal. Daarom zou men kunnen stellen dat levensbeschouwingen - en dus ook haar georganiseerde vormen - niet (langer) moeten worden opgevat als niet-perfectionistische goederen, maar als perfectionistische goederen: voor sommige burgers is een (georganiseerde) levensbeschouwing nog zeer belangrijk, maar dit is niet zo voor iedereen. Het is daarom niet nodig om levensbeschouwingen als overheid te ondersteunen.

\section{Religie en godsdienstvrijheid}

Aansluitend op de vorige paragraaf moeten we nog een belangrijk onderscheid aanstippen dat vaak over het hoofd wordt gezien in discussies over de godsdienstvrijheid, de scheiding van kerk en staat, overheidsneutraliteit en financiële steun voor levensbeschouwingen. Het betreft het onderscheid tussen de vrijheid van godsdienst enerzijds, en het statuut van (geïnstitutionaliseerde) religie anderzijds. Het feit dat religies (en particuliere religieuze organisaties) als perfectionistische goederen worden opgevat, betekent met name niet dat de godsdienstvrijheid ook een perfectionistisch goed zou zijn. Binnen het politiek liberalisme is de godsdienstvrijheid immers essentieel: opdat iedereen de mogelijkheid zou hebben om zijn of haar leven in te richten volgens de principes die men onderschrijft, moet de vrijheid van godsdienst voor iedereen gegarandeerd zijn.

Maar impliceert dit recht op godsdienstvrijheid ook dat de overheid levensbeschouwelijke organisaties moet ondersteunen? Volgens sommigen is dit inderdaad het geval: een hands-offbeleid met betrekking tot religie zou niet volstaan om de vrijheid van godsdienst (en in het bijzonder de vrije uitoefening ervan) de facto voor iedereen te garanderen en daarom moet de overheid religie actief ondersteunen. Dit is echter een voorbarige en ongenuanceerde conclusie. In de Verenigde Staten bijvoorbeeld, is er een wall of separation tussen kerk en staat, wat onder meer betekent dat levensbeschouwingen geen directe overheidssubsidies krijgen. Dit impliceert echter niet dat de vrijheid van godsdienst in de VS hierdoor zou worden aangetast - integendeel: anders dan in vele Europese landen waar religies actief door de overheid gesubsidieerd worden, lijkt religie in de VS prominenter aanwezig te zijn dan in Europa en ook de secularisering lijkt er moei- 
zamer op gang te komen. Bovendien blijkt uit jurisprudentie op het hoogste niveau dat de Amerikaanse overheid de godsdienstvrijheid zeer ernstig neemt. ${ }^{18}$

Volgens sommige sociologen bewijst dit opmerkelijke verschil tussen Amerika en Europa dat overheidssteun voor levensbeschouwingen contraproductief werkt. Als alternatief bepleiten zij, conform het Amerikaanse systeem, een vrije religieuze markteconomie. Binnen een dergelijk systeem concurreren religies met elkaar en religies die niet aantrekkelijk genoeg zijn, verdwijnen automatisch: 'The more pluralism, the greater the religious mobilization of the population - the more people there are who will be committed to a faith. ${ }^{19}$

Het is dus vanuit een theoretisch perspectief in feite voldoende om de godsdienstvrijheid te garanderen als een formeel recht. En ook vanuit het perspectief van de mensenrechten is er geen 'clear-cut right for organized religions to be funded by the state'. ${ }^{20}$ Het formeel garanderen van de vrijheid van godsdienst volstaat. Een analogie met het recht op vrijheid van vereniging kan dit verduidelijken: ook dit recht is een primair goed dat voor iedereen gevrijwaard moet zijn. Niemand beweert echter dat de overheid hiertoe verenigingen actief moet ondersteunen $-\mathrm{al}$ is dit wel een legitieme mogelijkheid. Op een gelijkaardige manier is het recht op godsdienstvrijheid een primair goed, maar moet de overheid (georganiseerde) religie niet noodzakelijk ondersteunen om dit recht te garanderen - al is ook hier overheidssteun een legitieme mogelijkheid.

We kunnen dus besluiten dat de vrijheid van godsdienst een primair (en dus nietperfectionistisch) goed is, terwijl (georganiseerde/geïnstitutionaliseerde) religies en niet-religieuze levensbeschouwingen perfectionistische goederen zijn. Dit sluit echter dit niet uit dat levensbeschouwelijke groeperingen en organisaties door de overheid gesubsidieerd kunnen worden - wat trouwens de gangbare praktijk is in heel wat westerse liberale democratieën. Maar waarom zou een liberale overheid overgaan tot dergelijke steun? De legitimering hiervoor moet antiperfectionistisch of neutraal zijn wil een liberale overheid al haar burgers gelijke kansen geven om een leven te leiden volgens hun opvattingen over het goede leven, maar dit blijkt niet zo vanzelfsprekend.

18 Zie hierover bijv. Martha Nussbaum, Liberty of Conscience; Kent Greenawalt, Religion and the Constitution (volume I \& II) (Princeton: Princeton University Press, 2009); Christopher C. Eisgruber \& Lawrence G. Sager, Religious Freedom and the Constitution (Cambridge: Harvard University Press, 2007).

19 Roger Finke \& Rodney Stark, 'Religious Economies and Sacred Canopies: Religious Mobilization in American Cities, 1906’, American Sociological Review 53(1) (1988): 42-43.

20 Jeroen Temperman, State-Religion Relationships and Human Rights Law: Toward a Right to Religiously Neutral Governance (Leiden/Boston: Martinus Nijhoff, 2010), 254. 


\section{Autonomy-based liberalisme en overheidssteun voor perfectionistische goederen}

Zoals aangetoond zijn levensbeschouwingen perfectionistische goederen: voor sommige burgers zijn ze belangrijk, maar dit is niet voor iedereen zo. Bovendien blijkt overheidssteun voor georganiseerde levensbeschouwingen niet noodzakelijk om de vrijheid van godsdienst te garanderen. Op basis van deze vaststellingen elke vorm van overheidssteun voor levensbeschouwingen afkeuren zou echter voorbarig en onjuist zijn. Wanneer een substantieel deel van de bevolking een bepaalde levensbeschouwing als een 'waardevolle optie' beschouwt (wat in zowat alle samenlevingen het geval blijkt te zijn), brengt het autonomy-based liberalisme immers met zich mee dat deze burgers toegang moeten hebben tot deze optie (en tot andere opties die ze waardevol vinden). Autonomy-based liberalisme impliceert namelijk niet enkel dat burgers de mogelijkheid moeten hebben om voor zichzelf te beslissen wat waardevol is en wat niet, maar ze moeten ook steeds de mogelijkheid hebben om hun leven in overeenstemming te brengen met deze beslissing: 'Autonomy is an ideal of people deciding for themselves what is a valuable life, and living their lives in accordance with that decision. ${ }^{21}$ Anders gezegd: de liberale overheid moet autonomie niet enkel formeel garanderen, maar burgers moeten ook een reële mogelijkheid hebben om een leven te leiden volgens de waarden die zij onderschrijven en dit impliceert onder meer dat men gelijke toegang heeft tot een minimum aan waardevolle opties waaruit men kan kiezen. De overheid moet dus 'equal access to autonomy' ${ }^{22}$ garanderen en hiertoe moet ze gelijke toegang tot een adequaat aanbod aan waardevolle opties verschaffen.

Idealiter worden deze opties automatisch gegarandeerd binnen een fair marktsysteem: wanneer de overheid niet-perfectionistische goederen op een gelijke manier verdeelt en wanneer de vrije markt haar werk doet, zouden alle burgers in feite de mogelijkheid moeten hebben om een leven te leiden volgens de waarden die ze onderschrijven en zouden ze daadwerkelijk moeten kunnen kiezen uit een ruim pallet aan waardevolle opties. Dit is de meest ideale situatie in een liberale samenleving. Het is echter ook mogelijk - en in de praktijk vaak het geval - dat het vrijemarktmechanisme niet volstaat. Omwille van (aanhoudende) socioeconomische ongelijkheden is het vrijemarktsysteem jammer genoeg de facto vaak onvoldoende om een adequaat aanbod aan waardevolle opties voor iedereen te garanderen.

Om aan deze ongelijkheid tegemoet te komen en gelijke toegang tot autonomie voor iedereen te garanderen, zijn er twee mogelijkheden. De eerste, en meest aangewezen, is een herverdeling van niet-perfectionistische goederen: wanneer sommige burgers geen autonome keuzes kunnen maken omdat ze de facto geen toegang hebben tot een adequaat pallet aan waardevolle opties, moet de overheid in eerste instantie niet-perfectionistische goederen herverdelen zodat ook deze burgers effectief autonome keuzes kunnen maken. 
Wanneer dit echter niet de meest efficiënte manier is om voor iedereen gelijke toegang tot autonomie te garanderen, kan ook overheidssteun voor perfectionistische goederen toegelaten worden. Binnen het autonomy-based liberalisme kan de overheid dus een 'neutraal' argument geven om levensbeschouwingen (en andere perfectionistische goederen) financieel te ondersteunen: omdat alle burgers minstens de mogelijkheid moeten hebben om autonome keuzes te maken, moeten ze toegang hebben tot een toereikend pallet aan waardevolle opties. En aangezien overheidssteun voor dergelijke opties hiertoe een efficiënt middel kan zijn, is deze steun legitiem. Men zou zelfs kunnen zeggen dat dergelijke steun noodzakelijk is wanneer deze efficiënter is dan het vrijemarktsysteem en een herverdeling van niet-perfectionistische goederen. Een overheid dient immers niet alleen een zo rechtvaardig mogelijk, maar ook een zo efficiënt mogelijk beleid na te streven.

Hoewel er in een liberale, pluralistische samenleving geen unanieme consensus bestaat over de waarde van particuliere opties, kunnen burgers op basis van redelijke argumenten wel inzien dat een toereikend aanbod aan waardevolle opties noodzakelijk is om autonome keuzes te kunnen maken of voor 'effective deliberation about the good'. ${ }^{23}$ Deze burgers kunnen eveneens tot een overlappende consensus komen over het feit dat overheidssteun soms een efficiënt middel kan zijn voor dit doel. De idee die aan de basis ligt voor overheidssteun voor perfectionistische goederen (en dus ook voor levensbeschouwingen) is dus niet zo verschillend van de idee die aan de basis ligt voor overheidssteun voor niet-perfectionistische goederen: men kan, op redelijke gronden, verwachten dat elke burger overheidssteun voor een minimum aan waardevolle opties accepteert. In de woorden van Mills:

'citizens are subject to a range of autonomy-based duties towards one another, which help to create and sustain an adequate range of options and foster a range of inner capacities required for the conduct of an autonomous life. $^{24}$

De rechtvaardiging voor een ondersteuningsbeleid van perfectionistische goederen is hiermee neutraal of antiperfectionistisch: de overheid ondersteunt deze goederen of 'waardevolle opties' niet omdat ze waardevol zijn, maar omdat burgers een reële mogelijkheid tot autonome keuzes zouden hebben. Dit is een 'neutrale' of 'antiperfectionistische' legitimering omdat ze door alle redelijke en rationele burgers in een liberale samenleving onderschreven kan worden.

\section{$7 \quad$ De waarde van waardevolle opties}

Als de overheid in bepaalde situaties perfectionistische goederen of waardevolle opties mag ondersteunen, rijzen er onvermijdelijk twee cruciale vragen: de eerste 
is wat een optie precies tot een waardevolle optie maakt en de tweede is waar en hoe we een lijn kunnen trekken tussen toegelaten en niet-toegelaten steun voor dergelijke opties.

Vooreerst is er de vraag wat een optie precies tot een waardevolle optie maakt. Hierop zijn er binnen het autonomy-based liberalisme verschillende antwoorden mogelijk. Zo stelt Joseph Raz dat een optie intrinsiek waardevol kan zijn en daarom door de overheid ondersteund kan worden. ${ }^{25}$ De vraag wie er over deze waarde beslist en hoe dit gebeurt, blijft echter onbeantwoord bij Raz en deze lacune maakt zijn theorie vatbaar voor kritiek. Een ander probleem is dat het Raziaans perfectionisme uiteindelijk tot een inbreuk op onze individuele vrijheid kan leiden: de overheid steunt immers opties met ons belastinggeld omdat ze 'waardevol' zijn (wat dat ook moge betekenen), ook wanneer we zelf deze opties helemaal niet waardevol vinden en we dit geld liever zouden gebruiken voor dingen die we zelf waardevol vinden. Bovendien manipuleert de overheid de keuzes van haar burgers door bepaalde zaken te ontmoedigen en andere aan te bevelen en dit soort manipulatie valt niet te rijmen met het principe van autonomie. ${ }^{26}$

Ook Will Kymlicka geeft aan dat het Raziaanse staatsperfectionisme kan leiden tot een beperking van de individuele vrijheid. Als alternatief pleit hij daarom voor 'sociaal perfectionisme': ook al zou de overheid, zich baserend op onderzoek en expertise, kunnen bewijzen dat bijvoorbeeld het bijwonen van een theatervoorstelling waardevoller is dan het bijwonen van een worstelwedstrijd, dan nog is het niet toegestaan om, op basis van dit waardeoordeel, de eerste optie te ondersteunen en de laatste niet. Een dergelijk beleid leidt immers onvermijdelijk tot een 'illegitimate restriction of self-determination'. ${ }^{27}$ Het is niet aan de overheid om te bepalen welke opties waardevol zijn en welke niet. Dit evaluatief proces mag uitsluitend plaatsvinden in civil society. Meer zelfs: wanneer de liberale overheid binnen de samenleving een faire vrije markt garandeert, zullen verderfelijke opties automatisch het onderspit delven voor waardevolle opties: '[u]nder conditions of freedom, satisfying and valuable ways of life will tend to drive out those which are worthless and unsatisfying. ${ }^{28}$ Kymlicka pleit dus voor sociaal perfectionisme (of antiperfectionisme) en niet voor staatsperfectionisme: burgers - en niet de overheid - beslissen welke opties al dan niet waardevol zijn en burgers - en niet de overheid - zijn bereid om zelf voor deze opties te betalen wanneer ze deze waardevol vinden.

Met dit sociaal perfectionisme vermijdt Kymlicka dat de overheid bepaalde opties ondersteunt zonder inbreng van haar burgers en hierdoor manipulerend optreedt en/of hun autonomie inperkt. Hij gaat er echter te optimistisch van uit dat waardevolle opties automatisch overleven binnen een vrije markt en dus geen over-

Joseph Raz, The Morality of Freedom (Oxford: Oxford University Press, 1986), 200-201; 212-13.

Een uitvoerige kritiek op Raz vinden we onder meer in Jeremy Waldron, 'Autonomy and Perfectionism in Raz's Morality of Freedom', Southern California Law Review 62(3-4) (1989): 1097-1152.

Kymlicka, Contemporary Political Philosophy, 214.

Will Kymlicka, 'Liberal Individualism and Liberal Neutrality', Ethics 99(4) (1989): 884. 
heidssteun behoeven. Dit is echter niet zo vanzelfsprekend. Zowel het Raziaanse perfectionisme (staatsperfectionisme gebaseerd op de intrinsieke waarde van bepaalde opties) als Kymlicka's antiperfectionisme (sociaal perfectionisme, gebaseerd op sociale consensus) zijn daarom ontoereikend.

Een valabel alternatief vinden we bij Joseph Chan, die pleit voor staatsperfectionisme (de overheid mag waardevolle opties actief ondersteunen) in combinatie met sociaal perfectionisme en meer bepaald met het idee van democratische consensus. Chan's multicentered perfectionisme laat toe dat de overheid bepaalde opties ondersteunt, zonder dat ze hierover echter zelf een waardeoordeel velt. Dit oordeel wordt door individuele burgers gemaakt:

'(...) voluntary associations (...) take the primary and active role in promoting valuable goods and ways of life. The state might either not intervene at all if these groups are effective, or just assist in promoting the good by helping these associations. The state may need to take an active role in those areas where civil society fails. Alternatively, the state may work side by side with civil society.'29

In een multicentered perfectionistische staat kan de overheid nooit los van de samenleving bepalen welke opties, praktijken enzovoort al dan niet waardevol zijn en (daarom) steun behoeven: enerzijds heeft de samenleving de overheid nodig om aan haar (financiële) tekortkomingen tegemoet te komen, en anderzijds heeft de overheid een krachtdadige samenleving nodig om haar macht in te perken. Er is dus in principe geen diepe kloof tussen de samenleving (civil society) en de overheid - ten minste niet wat betreft het ondersteunen van 'waardevolle opties'. Meer zelfs: de samenleving en de overheid kunnen in feite niet zonder elkaar in het nastreven van bepaalde (perfectionistische) doeleinden. ${ }^{30}$ Een dergelijke vorm van 'democratisch perfectionisme' ${ }^{31}$ kan onder meer worden geïmplementeerd via een rotatiesysteem, waarin afgevaardigden uit diverse organisaties en belangengroepen verantwoordelijk zijn voor subsidies en beleidsopties met betrekking tot het subsidiëren van perfectionistische goederen. Om zo veel mogelijk rekening te houden met alle burgers, moeten deze afgevaardigden regelmatig (bijv. om de drie jaar) op een democratische manier verkozen worden. Een dergelijk systeem leidt er volgens Chan toe 'that most, if not all, major reasonable specific conceptions of goods would have a fair chance to be heard and supported by state funding in the long run'. ${ }^{32}$ Op deze manier blijven zowel de neutraliteit van de overheid, als de individuele autonomie gevrijwaard. (2000): 15-16.

30 Chan, Legitimacy, Unanimity, and Perfectionism, 33.

31 Zie voor deze term Amy Gutmann, 'Undemocratic Education', in Philosophy of Education. Major Themes in the Analytic Tradition. Volume III - Society and Education, eds. Paul H. Hirst \& Patricia White (London/New York: Routledge, 1998), 40.

32 Chan, Legitimacy, Unanimity, and Perfectionism, 33-34. 


\section{De morele boven- en ondergrens}

Als de overheid, op basis van waardeoordelen van haar burgers, heeft besloten om een aantal opties actief te ondersteunen, rijst onvermijdelijk de vraag waar en hoe we de lijn moeten trekken tussen toegelaten en niet-toegelaten steun. Allicht zal iedereen het ermee eens zijn dat de overheid niet moet instaan voor dure, luxueuze preferenties van haar burgers. Maar wanneer is overheidssteun moreel aanvaardbaar en wanneer niet?

Op deze vraag zijn verschillende antwoorden mogelijk. Zo zou de overheid het aantal waardevolle opties kunnen maximaliseren, zodat er zo veel mogelijk waardevolle opties zijn waaruit men kan kiezen. Omdat meer waardevolle opties echter niet noodzakelijk leiden tot meer autonomie (we hebben enkel 'voldoende' waardevolle opties nodig waaruit we kunnen kiezen) en omdat overmatige overheidssteun kan leiden tot een inperking van de individuele autonomie (omdat belastinggeld dan mogelijks wordt gebruikt voor opties die men zelf niet waardevol vindt, terwijl men zelf onvoldoende middelen heeft om de eigen preferenties na te streven), is dit geen goede oplossing. Wat telt is immers niet het feit dat we zo veel mogelijk keuzes hebben, maar dat we, als autonome wezens, reële keuzes kunnen maken. Dit vereist geen oneindig aanbod, maar slechts een voldoende aanbod aan opties:

'[N]either the instrumental, nor the noninstrumental value of having choices supports the view that more are always preferable to fewer. In the realm of choice, as in all others, we must conclude - enough is enough. ${ }^{33}$

Een betere mogelijkheid is daarom het maximaliseren van gelijkheid op het niveau van autonome keuzes. In dit geval wordt het aantal waardevolle opties niet gemaximaliseerd, maar ondersteunt de overheid een aantal waardevolle opties opdat er meer gelijkheid zou zijn op het niveau van het maken van autonome keuzes. Het doel van overheidssteun is dus het faciliteren van een toereikend pallet aan waardevolle opties, en niet het maximaliseren van deze waardevolle opties. Wanneer sommige burgers een museum willen bezoeken, terwijl anderen liever een wandeling in het park maken (wat minder duur is), is het vanuit dit perspectief niet onfair om de eerste optie meer te subsidiëren dan de laatste, op voorwaarde dat de volgende voorwaarden vervuld zijn: (1) noch het vrijemarktsysteem, noch een (her)verdeling van niet-perfectionistische goederen zijn voldoende om deze eerste optie op een efficiënte manier te garanderen; (2) overheidssteun is een efficiënt middel om deze optie te garanderen; en (3) overheidssteun leidt tot gelijke toegang tot waardevolle opties en dus tot meer gelijkheid om autonome keuzes te maken, zonder dat de individuele autonomie wordt ingeperkt.

De bottom line is dus een toereikend aanbod aan waardevolle opties. Of in Ben Colburns woorden: 'the autonomy-minded liberal would have good reason to design 
institutions that provide assistance for people who fall below the minimal capacities for living autonomously'. ${ }^{34}$ Méér overheidssteun is niet toegestaan omdat dit kan leiden tot een illegitieme beperking van de individuele autonomie. Maar ook minder (of helemaal geen) steun kan leiden tot een inperking van de individuele autonomie omdat sommige burgers in dit geval mogelijks geen reële toegang tot voldoende waardevolle opties hebben en ze dus niet de reële mogelijkheid hebben om autonome keuzes te maken.

Tot slot zijn er nog enkele belangrijke kanttekeningen bij dit alles. Ten eerste mag overheidssteun voor perfectionistische goederen (en dus ook voor levensbeschouwingen) nooit de algemene regel zijn, maar zou dergelijke steun in principe steeds de uitzondering moeten zijn. Idealiter volstaat de vrije markt om voldoende waardevolle opties voor iedereen te garanderen. Wanneer dit niet het geval is, moet de overheid in eerste instantie niet-perfectionistische goederen herverdelen opdat iedereen gelijke kansen heeft om autonome keuzes te maken. Enkel wanneer steun voor perfectionistische goederen efficiënter is dan een dergelijke herverdeling, is deze steun als pragmatische oplossing toegestaan, 'for as long as the inequality persists'. ${ }^{35}$

Verder moeten we een duidelijk onderscheid maken tussen gelijkheid van kansen op (individueel) welzijn (equality of opportunities for welfare) enerzijds, en gelijkheid van (individueel) welzijn (equality of welfare) anderzijds. Omdat we onze verlangens en preferenties niet passief ondergaan, maar op een verantwoorde manier autonome keuzes kunnen maken, moet de liberale overheid enkel het eerste garanderen, maar niet het laatste. ${ }^{36}$ Het feit dat we niet volledig autonoom zijn (omdat onze keuzes steeds beïnvloed worden door onze sociale omgeving, interesses, opvoeding, voorkeuren van onze ouders, enz.) en dat we onze preferenties niet zelf kiezen, impliceert geenszins dat we niet kunnen kiezen op welke manier we met deze preferenties omgaan. Precies daarom moet de overheid geen gelijke toegang tot al onze preferenties garanderen, maar moet ze enkel gelijke toegang tot een toereikend aantal waardevolle opties of preferenties garanderen. Wanneer dit gegarandeerd is en individuele burgers hun vrijheid en verantwoordelijkheid opnemen, zal dit automatisch leiden tot gelijkheid van welzijn.

Voorts kan men zich de vraag stellen wat er precies wordt bedoeld met 'voldoende' waardevolle opties: hoeveel waardevolle opties hebben we exact nodig om autonome keuzes te kunnen maken? Op deze vraag kan ik helaas geen sluitend antwoord geven. Het vereiste aantal waardevolle opties zal immers steeds afhankelijk zijn van de context en de samenleving waarin we ons bevinden. Daarom

35 Brian Barry, Culture and Equality: An Egalitarian Critique of Multiculturalism (Harvard: Harvard University Press, 2001), 13.

36 Zie over deze problematiek ook Rutger Claassen, die in een recent artikel (Rutger Claassen, 'Public Goods, Mutual Benefits, and Majority Rule', Journal of Social Philosophy 44[3] [2013]: 270-90) overheidssteun voor perfectionistische goederen ('discretionary public goods') op basis van democratische meerderheid bepleit en hiermee nauw aansluit bij de ideeën die ik hier uitwerk. 
moeten we het overlaten aan individuele burgers om hierover binnen de democratische besluitvorming te beslissen.

Tot slot nog dit: mogelijks zullen critici erop wijzen dat het onmogelijk is om op een autonome manier te 'kiezen' voor een welbepaalde religie of levensbeschouwing. In lijn met het communitarisme kan men inderdaad stellen dat mensen hun levensbeschouwing niet autonoom kiezen, maar dat ongekozen omstandigheden zoals de overtuiging van ouders en de culturele en religieuze achtergrond een bepalende rol spelen. Bovendien is niet autonomie, maar heteronomie eigen aan religie: men kiest niet voor een welbepaalde religie, maar religie 'overkomt' je. Hoewel er inderdaad heel wat externe, heteronome factoren zijn die onze levensbeschouwelijke identiteit beïnvloeden, neemt dit niet weg dat burgers in een liberale democratie steeds de mogelijkheid moeten hebben om zich van hun geloof te distantiëren. Precies daarom vat ik religie op als iets waarvoor men uiteindelijk autonoom kan kiezen. Dit samengaan van externe factoren en autonomie is overigens niet eigen aan religie, maar typeert zowat al onze keuzes. De keuze om bijvoorbeeld een muziekinstrument te bespelen, beschouwen we als een autonome keuze, maar ook hier spelen heel wat externe factoren zoals opvoeding, interesse van ouders en sociale omgeving een cruciale rol. Waar het in mijn argument om gaat is dat burgers in een liberale democratie minstens de mogelijkheid moeten hebben om voor dergelijke activiteiten/opties te kiezen en om er afstand van te nemen wanneer ze dit wensen. En om dit alles mogelijk te maken, kan overheidssteun voor perfectionistische goederen - en dus ook voor levensbeschouwingen - legitiem zijn.

We kunnen concluderen dat een liberale overheid ervoor kan kiezen om perfectionistische goederen (in casu levensbeschouwingen) financieel te ondersteunen, maar idealiter is een dergelijk beleid eerder de uitzondering dan de regel. Als de overheid er echter voor kiest om dit te doen, rijst de vraag welke goederen al dan niet ondersteund mogen worden. Hier sluipt het perfectionisme onvermijdelijk binnen. De keuze om als overheid specifieke perfectionistische goederen (bijv. religie of kunst; of boeddhisme en katholicisme) te ondersteunen kan onmogelijk neutraal zijn en hoeft dit ook niet te zijn: burgers kunnen in het democratische debat aangeven welke goederen ze waardevol vinden en daarom ondersteund willen zien en hiervoor mogen ze perfectionistische of niet-neutrale redenen geven. ${ }^{37}$ Om als overheid de neutraliteit te behouden is het echter noodzakelijk dat deze perfectionistische overwegingen steeds door burgers gemaakt worden (bijv. via een systeem zoals door Chan wordt voorgesteld) en niet door de staat. Daarom horen

37 Zie hierover ook Claassen, Public Goods, 286: 'All kinds of arguments may be used to convince the other side that this is reasonable. Here even considerations of intrinsic value (...) may return to the table.' Ook Rawls geeft dit aan in zijn A Theory of Justice ( $(43)$. Anders dan Rawls meen ik echter dat we geen onderscheid moeten maken tussen een apart exchange budget enerzijds, dat binnen de exchange branch gebruikt kan worden om perfectionistische goederen te financieren, en het national budget anderzijds, dat gebruikt wordt om niet-perfectionistische goederen te ondersteunen. Zolang een steunbeleid dient om iedereen op een zo efficiënt mogelijke manier toegang tot autonomie te verschaffen, is zo een beleid 'neutraal' en daarom mag er gebruik worden gemaakt van het nationale budget of van collectieve middelen. 
ze thuis in het democratische besluitvormingsproces en niet in vaststaande (constitutionele) wetten.

\section{Overheidssteun voor levensbeschouwingen in de grondwet}

In verschillende Europese constituties en gelijkgestelde wetten wordt overheidsfinanciering van levensbeschouwingen (grond)wettelijk vastgelegd. Zo bepaalt $\S 6$ van artikel 137 van de Duitse Weimarconstitutie (dat samen met art. 136, 138, 139 en 140 deel uitmaakt van de Duitse grondwet) dat het voor 'Religionsgesellschaften, welche Körperschaften des öffentlichen Rechtes sind', toegestaan is om 'auf Grund der bürgerlichen Steuerlisten nach Maßgabe der landesrechtlichen Bestimmungen Steuern zu erheben'. Dichter bij huis bepaalt het Belgische grondwetsartikel 181 dat 'de wedden en pensioenen van de bedienaren der erediensten' en van de 'door de wet erkende organisaties die morele diensten verlenen op basis van een niet-confessionele levensbeschouwing' ten laste van de Staat komen. In diezelfde Grondwet bepaalt artikel 24 dat 'alle leerlingen die leerplichtig zijn, (...) ten laste van de gemeenschap recht op een morele of religieuze opvoeding [hebben]', wat betekent dat de overheid de leerkrachten van de levensbeschouwelijke vakken in officiële en erkende vrije scholen bezoldigt. ${ }^{38}$

Een dergelijke (grond)wettelijke verankering van overheidssubsidies voor levensbeschouwingen is echter problematisch. Overheidssteun voor georganiseerde levensbeschouwingen is immers niet noodzakelijk om onze basisrechten en vrijheden (incl. de godsdienstvrijheid) te garanderen en ook zonder (gesubsidieerde) levensbeschouwelijke vakken kunnen de vrijheid van onderwijs en de vrijheid van godsdienst gegarandeerd worden. Er is dan ook geen enkele reden om overheidssteun voor levensbeschouwingen a priori (i.e. in een grondwet of een gelijkgestelde wet) vast te leggen.

Zich baserend op het Rawlsiaanse onderscheid tussen de principes van gelijkheid en van verschil stelt ook Matteo Bonotti dat kerk-staatverhoudingen niet in constitutionele wetten mogen worden vastgelegd. Ze behoren immers tot the principles covering social economic inequalities'39 en zijn geen noodzakelijke voorwaarde voor onze basisrechten en vrijheden. Vanuit het autonomy-based liberalisme komen we tot een gelijkaardige conclusie: ook zonder overheidssteun voor levensbeschouwingen kunnen onze basisrechten en vrijheden (incl. de godsdienstvrijheid) gegarandeerd worden. Wanneer er onvoldoende draagvlak is om (bepaalde) levensbeschouwingen als overheid te subsidiëren en burgers hiertoe toch verplicht worden, kan dit bovendien leiden tot een aanfluiting van de godsdienstvrijheid en dus ook van de individuele autonomie. Bijgevolg moet een

38 Officiële scholen in België komen overeen met de openbare scholen in Nederland, terwijl de Belgische vrije scholen overeenkomen met wat men in Nederland bijzondere scholen noemt.

39 Matteo Bonotti, 'Beyond Establishment and Separation: Political Liberalism, Religion and Democracy,' Res Publica 18 (2012): 339. 
dergelijk steunbeleid steeds de uitkomst zijn van een democratisch deliberatief proces en mag het niet verankerd worden in (grond)wettelijke tradities:

'Once a legitimate measure (e.g. to support religious schools with public funds) has been implemented, it is important that those citizens who oppose it have the opportunity to provide arguments against it and revoke it. This would not be possible if that decision was permanently withdrawn from democratic debate. ${ }^{40}$

Overigens is de (grond)wettelijke verankering van overheidssteun voor levensbeschouwingen (en dus ook voor godsdienstonderwijs) ook onwenselijk omdat ze de plaats van levensbeschouwing in de samenleving institutioneel verankert in a more permanent way than the measures of ordinary legislative politics do. ${ }^{41}$ Dit leidt onvermijdelijk tot verstarring en behoudzucht. Zo hebben verschillende politici in België al wel gewezen op de nood aan hervorming van het financieringssysteem van levensbeschouwingen, maar de constitutionele verankering bemoeilijkt het debat en wordt al te vaak gebruikt als conversation stopper, waardoor een grondig debat moeilijk op gang komt.

Ook de discussie over godsdienstonderwijs in België wordt vaak te snel van tafel geveegd door te wijzen op het 'grondwettelijke recht' op levensbeschouwelijk onderwijs - alsof dergelijk recht een toe te juichen en onaanraakbare verworvenheid is. Allicht was dit ten tijde van het schoolpact (1958), ${ }^{42}$ wel het geval, maar anno 2015 is niet iedereen nog overtuigd van het nut van levensbeschouwelijk onderwijs in één welbepaalde traditie. In een liberale democratie is er niets verkeerd met het organiseren en bekostigen van dergelijk onderwijs, zolang dit een keuze is die tot stand is gekomen na democratisch overleg en die dus gemakkelijk herzien kan worden.

Bovendien is het opmerkelijk dat er in diverse grondwettelijke tradities expliciet melding wordt gemaakt van (een verbod op) overheidssubsidies voor religies, terwijl er over andere perfectionistische goederen niets wordt gezegd. Er bestaat geen enkele grondwet die de overheid verplicht of verbiedt om musea, concertzalen en dansscholen te subsidiëren; er bestaat geen enkele grondwet die de overheid verplicht of verbiedt om voetbaltrainers met overheidsgeld te bezoldigen. Welnu, op een analoge manier zou er geen enkele grondwet mogen zijn die de

40 Bonotti, Beyond Establishment and Separation, 343.

41 Bonotti, Beyond Establishment and Separation, 335.

42 Dit schoolpact is een verzuild compromis tussen katholieken (verdedigers van het vrij [privaat/ bijzonder] onderwijs) en vrijzinnigen (verdedigers van het officieel [publiek/openbaar] onderwijs) en moest een einde maken aan de Belgische schoolstrijd. In dit schoolpact, dat geïmplementeerd werd in de Schoolpactwet van 1959 en later ook in de herziene Grondwet van 1988 (art. 24), stonden vier beginselen centraal: (1) het bestaan van officiële en vrije scholen; (2) de keuzevrijheid van ouders voor een officiële of een vrije school; (3) overheidssubsidiëring voor het vrij onderwijs; en (4) keuze uit 'onderricht in de katholieke, protestantse of Israëlitische eredienst (...) en in de niet-confessionele zedenleer' (art. 8) in het officieel (lager en secundair) onderwijs. 
overheid verplicht of verbiedt om geïnstitutionaliseerde levensbeschouwingen te subsidiëren of om godsdienstleerkrachten te bezoldigen. Daar het hier telkens over perfectionistische goederen (kunst, sport, religie) gaat, mag overheidssteun nooit a priori verplicht worden.

Maar ook het a priori (bij grondwet of een equivalent) verbieden van overheidssubsidies voor levensbeschouwingen, zoals bijvoorbeeld in het Franse kerk-staatmodel, kan principieel niet door de liberale beugel. Zo wordt er wat betreft de financiering van religie in Frankrijk halsstarrig vastgehouden aan de Loi du 9 décembre 1905 concernant la séparation des Eglises et de l'Etat, waarin erkenning, financiering en overheidssteun voor 'cultes' in Art. 2, § 1 (1905) uitdrukkelijk verboden wordt: 'La République ne reconnaît, ne salarie ni ne subventionne aucun culte.' Een dergelijk verankerd verbod op het subsidiëren van levensbeschouwingen is echter niet 'liberaal'. Meer zelfs: een (grond)wettelijk verbod op overheidssubsidies voor levensbeschouwingen kan in sommige gevallen (net zoals een wettelijke verplichting op subsidies) leiden tot een inperking van de godsdienstvrijheid, met name wanneer een dergelijk verbod de de facto uitoefening van de godsdienst bemoeilijkt of zelfs onmogelijk maakt.

In dit verband spreekt Wibren van der Burg over het belang van compenserende neutraliteit. ${ }^{43}$ Deze vorm van neutraliteit - die onder meer gestalte kan krijgen in het financieren van religies - kan soms vereist zijn opdat minderheden niet enkel de iure, maar ook de facto gelijke kansen en mogelijkheden (om hun religie ook in de praktijk te belijden) hebben. 'In bijzondere gevallen' is het inderdaad aangewezen dat de liberale overheid extra steun geeft, bijvoorbeeld 'voor de migrantenkerk die zonder startlening het kerkgebouw niet kan aankopen omdat ze anders dan de gevestigde kerken nog geen vermogen heeft opgebouwd en haar leden tot de minst draagkrachtigen behoren'. Dergelijke compenserende neutraliteit kan nodig zijn als 'correctiemechanisme omdat de vrije markt en het politieke systeem niet altijd perfect werken', maar zoals gezegd zouden dergelijke uitzonderingsregels in principe slechts tijdelijk mogen worden toegestaan, als pragmatische oplossing. Bovendien geldt ook hier dat steun niet a priori mag worden vastgelegd, maar enkel legitiem is wanneer burgers (i.c. de levensbeschouwelijke minderheden) hier vragende partij voor zijn.

\section{Overheidssteun voor levensbeschouwingen: criteria}

Opdat een overheid perfectionistische goederen (en dus ook levensbeschouwingen) mag subsidiëren moet er aan een aantal voorwaarden voldaan zijn. Zo moet de overheid eerst en vooral proberen om iedereen gelijke toegang tot autonomie te verschaffen door een faire vrije markt te garanderen en door een aantal nietperfectionistische goederen (bijv. onderwijs en gezondheidszorg) te ondersteunen. Idealiter volstaat dit beleid om iedereen toegang te verschaffen tot een ade- 
quaat aanbod aan waardevolle opties. Wanneer een dergelijk overheidsbeleid echter de facto minder efficiënt blijkt te zijn dan een beleid waarin ook perfectionistische goederen worden ondersteund, kan de overheid, onder een aantal strikte voorwaarden en als tijdelijke en pragmatische oplossing, kiezen voor een aanvullend ondersteuningsbeleid van perfectionistische goederen, waartoe ook levensbeschouwingen kunnen behoren. Dit is echter steeds een second-best option: idealiter volstaan een faire (her)verdeling van niet-perfectionistische en primaire goederen en een faire vrije markt. Enkel wanneer het vrijemarktprincipe niet volstaat en een herverdeling van niet-perfectionistische goederen niet efficiënt genoeg is om voor iedereen een toereikend pallet aan waardevolle opties te garanderen, is een steunbeleid voor perfectionistische goederen legitiem.

Ook zal er, binnen het autonomy-based liberalisme, steeds een maatschappelijk draagvlak moeten zijn om specifieke perfectionistische goederen te subsidiëren: enkel wanneer burgers vragende partij zijn om bijvoorbeeld levensbeschouwingen te subsidiëren, kan de overheid hiertoe overgaan. Vermits er geen unanieme consensus bestaat over de waarde van diverse perfectionistische goederen, moet een ondersteuningsbeleid zo veel mogelijk worden afgestemd op de vraag van de burgers en moet het een open beleid zijn. Dit betekent dat alle perfectionistische goederen (kunst, levensbeschouwing, sport, kooklessen, hobbyclubs) principieel gelijke kansen op ondersteuning (of erkenning) moeten hebben.

Verder is een steunbeleid voor perfectionistische goederen (i.c. levensbeschouwingen) enkel legitiem wanneer niemand door dit steunregime substantieel benadeeld wordt. Een steunbeleid moet steeds meer gelijke kansen (om daadwerkelijk autonome keuzes te kunnen maken) opleveren, zonder dat dit gepaard gaat met minder kansen voor dat deel van de bevolking dat er toevallig niet-ondersteunde preferenties op nahoudt. Mijn belastingbijdrage aan de katholieke kerk is dus enkel legitiem wanneer medeburgers dankzij deze collectieve subsidies gelijke kansen hebben om hun geloof uit te oefenen en wanneer ze zonder deze steun onvoldoende toegang zouden hebben tot deze waardevolle optie, wat hun de facto mogelijkheid om autonome keuzes te maken zou inperken. Het feit dat $i k$ toevallig niet geloof en geen gebruik maak van dit perfectionistisch goed, doet hier geen afbreuk aan, op voorwaarde dat het voordeel van dit steunbeleid (garanderen van gelijke toegang tot een toereikend pallet aan waardevolle opties voor iedereen) substantiëler is dan mijn geleden nadeel (mijn belastingbijdrage voor de katholieke kerk) en dat ik nog steeds autonoom kan kiezen om mijn eigen preferenties na te streven.

De voorgaande criteria zouden we primaire criteria kunnen noemen: het zijn noodzakelijke voorwaarden opdat de overheid tot een steunbeleid kan overgaan. Zonder deze voorwaarden is een steunbeleid niet legitiem. Maar ook van zodra de overheid heeft gekozen voor een actief ondersteuningsbeleid van levensbeschouwingen, moeten er een aantal criteria vervuld zijn. Deze zouden we secundaire criteria kunnen noemen. 
Zo dienen de gesubsidieerde levensbeschouwingen de principes van een rechtvaardige samenleving (vrijheid, gelijkheid) te respecteren: wanneer ze ingaan tegen deze principes, is het niet geoorloofd om deze als liberale overheid te ondersteunen. Omdat een dergelijk beleid echter niet altijd in overeenstemming is met de vrijheid van godsdienst en van vereniging, zou de overheid ervoor kunnen kiezen om sommige levensbeschouwingen die intern de principes van vrijheid en gelijkheid niet toepassen, toch toe te laten. Op dit punt zijn er wel gradaties: zo is er bijvoorbeeld een wezenlijk verschil tussen het besnijden van jonge meisjes enerzijds - een praktijk die onomkeerbaar is en/of waarbij er geen reëel recht op exit is en het uitsluiten van vrouwen voor het priesterambt anderzijds - een praktijk die niet onomkeerbaar is en/of waar er een reëel recht op exit is. Om het recht op vereniging en de vrijheid van godsdienst te eerbiedigen én tegelijkertijd rekenschap te geven van een rechtvaardig beleid, kan de overheid levensbeschouwingen die de principes van vrijheid en gelijkheid intern niet respecteren wel toelaten en zelfs financieel ondersteunen, mits er een aantal voorwaarden vervuld zijn. Zo mag er geen sprake zijn van schade aan derden, moeten er reële exitopties gegarandeerd zijn en moeten burgers correct worden ingelicht over deze exitopties. ${ }^{44}$

Verder mag niemand door de overheid verplicht worden om van de ondersteunde levensbeschouwing gebruik te maken. Wanneer individuen kiezen voor of vasthouden aan opvattingen en voorkeuren die de overheid niet ondersteunt, mag de overheid niet ingrijpen in deze keuze, tenzij ze zou leiden tot een beperking van de vrijheden van derden. Wie ondanks de overheidssteun voor levensbeschouwingen nooit een kerk of synagoge binnenstapt, mag hiertoe nooit verplicht worden of in het nadeel gesteld worden: enkel op die manier wordt de autonome keuze van de burger ten volle gerespecteerd. Met andere woorden, de overheid mag levensbeschouwingen wel ondersteunen als daar vanuit civil society voldoende draagvlak voor is, maar er mag nooit sprake zijn van dwang om ook gebruik te maken van deze perfectionistische publieke goederen.

Bovendien moeten levensbeschouwingen, wanneer ze eenmaal ondersteund worden, volgens dezelfde principes en regels - i.e. even-handed - ondersteund worden. De overheid zal dus niet alleen moeten diversifiëren tussen diverse perfectionistische goederen, maar ook wanneer een bepaald perfectionistisch goed (bijv. levensbeschouwing) in aanmerking komt voor overheidssteun, zal de overheid moeten differentiëren en diverse levensbeschouwingen gelijke kansen op ondersteuning (of erkenning) moeten geven. Daarnaast moet het overheidsbudget voor levensbeschouwingen steeds op een proportionele manier verdeeld worden.

44 Levensbeschouwelijke organisaties zijn op dit punt overigens niet fundamenteel verschillend van niet-levensbeschouwelijke organisaties. Zo kunnen bijv. voetbalclubs enkel mannelijke spelers toelaten en mogen dansscholen mannen weigeren als dit wezenlijk is voor de aard van de activiteit die beoefend wordt. De vrijheid van vereniging laat immers toe dat organisaties bepaalde eisen van haar leden kunnen stellen als dit nodig is voor de aard van de activiteit of organisatie, zolang het recht op exit steeds gegarandeerd is, burgers correct geïnformeerd worden over andere 'opties' en derden (niet-leden) niet geschaad worden. 
Tot slot mag de overheid haar keuze om levensbeschouwingen - of andere perfectionistische goederen - te subsidiëren nooit baseren op enig waardeoordeel. Zoals ik heb aangetoond is er een neutrale of niet-perfectionistische legitimering mogelijk voor een dergelijk beleid: om een toereikend aanbod aan waardevolle opties te garanderen (wat een mogelijkheidsvoorwaarde is om autonome keuzes te kunnen maken) kan de overheid in bepaalde omstandigheden en onder bepaalde voorwaarden niet-perfectionistische goederen, zoals levensbeschouwingen, ondersteunen. Als ze tot een dergelijk beleid overgaat, is dit enkel legitiem wanneer burgers hiervoor vragende partij zijn en wanneer civil society - en niet de overheid - bepaalt welke opties al dan niet ondersteund worden. Enkel op die manier blijft de neutraliteit van de staat behouden en kunnen burgers daadwerkelijk een leven leiden volgens de waarden en opvattingen die ze zelf onderschrijven. 